Urszula Wybraniec-Skardowska

Uniwersytet Kardynała Stefana Wyszyńskiego, Warszawa

ORCID: 0000-0001-9539-7482

e-mail: skardowska@gmail.com

\title{
Dwojaka natura ontologiczna znaków językowych i problem ich wzajemnych relacji*
}

\section{Wprowadzenie}

Zagadnienie statusu ontologicznego znaków językowych wiąże się z ogólniejszym problemem filozoficznym: Czym jest język jako system znaków służący do reprezentowania wiedzy o poznawanej rzeczywistości, do zgłębiania tej wiedzy oraz lepszego poznawania czy odkrywania rzeczywistości, adekwatnego jej opisu i interpersonalnego komunikowania się jego użytkowników? Wszystkie te pragmatyczne funkcje języka wymagają logiczno-filozoficznej jego analizy. Nie jest ona możliwa bez określenia, jak pojmowane są znaki językowe i jaka jest ich ontologiczna natura.

W analizie semiotycznej, a także lingwistycznej, używane są zarówno typy, jak i egzemplarze znaków, często jednak bez zwracania należytej uwagi, kiedy mowa o typach, a kiedy o egzemplarzach. Ma to związek z dyskutowanymi wciąż w filozofii języka problemami: Czym jest typ znaku? Czym jest egzemplarz (okaz) znaku? Jakie są wzajemne relacje pomiędzy typem a egzemplarzem? (ang. type-token relation, token-type relation).

Spory $\mathrm{w}$ odpowiedzi na te pytania mają związek z zagadnieniami egzystencjalnymi dotyczącymi statusu ontologicznego tych znaków

\footnotetext{
Odczyt wygłoszony na XI Zjeździe Filozoficznym w Lublinie, wrzesień 2019.
} 
językowych oraz dwoma nurtami w ontologii języka, pozostającymi pod wpływem dwóch fundamentalnych idei, które ukształtowały się w sporze o uniwersalia: nominalizmem i realizmem.

W pracy zostaną krótko przedstawione różne stanowiska w sprawie poruszanych powyżej zagadnień czy problemów oraz przeanalizowane logiczne konsekwencje wynikające z opowiedzenia się za którymś ze stanowisk.

\section{Funkcjonalne podejście do języka jako systemu znaków Dwa sposoby użycia znaków}

W procesie poznania rzeczywistości zdobywamy wiedzę o niej, gromadzimy ją w jakimś systemie wiedzy oraz reprezentujemy ją $w$ jakimś systemie znakowym, zazwyczaj językowym. W języku zgłębiamy tę wiedzę oraz przetwarzamy ją. Prowadzi to nas do nowej wiedzy o interesującej nas rzeczywistości lub do jej odkrywania.

Efektywność poznania jest zależna od wzajemnych relacji pomiędzy elementami triady: język-wiedza-rzeczywistość. Jest ona osiągana, gdy język, jego składnia, odzwierciedla adekwatnie jego semantykę, a więc gdy język służy do adekwatnego opisu tej rzeczywistości ${ }^{1}$, a także - skutecznego interpersonalnego komunikowania się jego użytkowników.

Wymienione wcześniej pragmatyczne funkcje języka wymagają filozoficznej i logicznej analizy - zarówno jego składni, jak i semantyki. Taka analiza jest związana z pojmowaniem znaków, ich ontologiczną naturą w funkcjonalnym podejściu do jezzyka ${ }^{2}$, osadzonym na dwóch sposobach ich użycia: bądź jako znaków, którymi posługujemy się w konkretnych kontekstach sytuacyjnych czy sytuacyjno-językowych, bądź jako znaków izolowanych, oderwanych z takich kontekstów. W tym pierwszym wypadku są one konkretami językowymi, istniejącymi, materialnymi, spostrzegalnymi zmysłowo obiektami o określonej lokalizacji czasoprzestrzennej. W tym drugim - są one nie-konkretami, a jako takie (jak

1 Zob. Urszula Wybraniec-Skardowska, „O adekwatności językowej”, w: Deskrypcja i prawda, red. Jerzy Pelc (Warszawa: Polskie Towarzystwo Semiotyczne, 2010), 275-306; tenże. „On language adequacy”, Studies in Logic, Grammar and Rhetoric 40, 53 (2015): 247-292.

2 Pojęcie to zostało wprowadzone i przedyskutowane przez Jerzego Pelca w pracach: Jerzy Pelc, „Funkcjonalne podejście do semiotyki logicznej języka naturalnego”, w: Semiotyka polska 1894-1969, wyboru dokonał oraz wstępem i przypisami opatrzył Jerzy Pelc (Warszawa: PWN, 1971), 397-430; tenże, Studies in Functional Logical Semiotics of Natural Language, "Janua Linguarum Series Minor" 90 (The Hague-Paris: Mouton, 1971). 
przyjmuje większość badaczy z zakresu filozofii i lingwistyki) obiektami abstrakcyjnymi, typami językowymi.

\section{Charlesa Sandersa Peirce'a dystynkcja: type-token znaku}

Rozróżnienie abstrakt-konkret (ang. type-token distinction) ma już we współczesnej filozofii pewien status i jest znaczące zwłaszcza w metafizyce i epistemologii. Jest ono najczęściej ilustrowane właśnie w odniesieniu do znaków językowych (słów, wyrażeń) jako dystynkcja typ-egzemplarz znaku wprowadzona do semiotyki przez Ch. S. Peirce'a (1906 i 1908). Przytoczę parę fragmentów z jego prac, w których po raz pierwszy pojawiają się pojęcia token (konkret, egzemplarz, okaz) i type (typ) w odniesieniu do słów:

A common mode of estimating the amount of matter in a MS. or printed book is to count the number of words. There will ordinarily be about twenty thes on a page, and of course they count as twenty words. In another sense of the word "word", however, there is one word "the" in the English language: it is impossible that this world should lie visibly on page or heard in any voice, for the it is not a Single thing or Single event. It does not exist; it only determines things that do exist. Such a definitely significant form, I propose to term a Type. A Single event which happens once and whose identity is limited to that one happening or a Single object or thing which is in some single place at any one instant of time, such event or thing being significant only as occurring just when and where it does, such as this or that word on single line of a single page of a single copy of a book, I will venture to call a Token ${ }^{3}$.

W listach Peirce'a do Lady Welby (1908) znajdujemy inne stosowne fragmenty:

A Sign may itself have a "possible" Mode of Being. E.g. A hexagon inscribed in or circumscribed about a conic. It is a Sign, in that the collinearity of the intersections of opposite sides shows the curve to be a conic, if the hexagon is inscribed; but if it be circumscribed the copunctuality of its three diameters (joining opposite vertices.) Its mode of Being may be Actuality: as with any barometer. Or Necessitant: as the word "the" or any other in the dictionary. For a "possible" Sign I have no better designation

${ }^{3}$ Charles S. Peirce, „Prolegomena to an Apology for Pragmaticism”, Monist 16 (1906): 505-506, 512. 
than a Tone, though I am considering replacing this by "Mark." [-] An Actual sign I call a Token; a Necessitant Sign a Type 4 .

A Sign may be an Occurrence, such as any one of a score of "thes" on a single page of single copy of an English book. I call such a Sign a Token ${ }^{5}$.

W analizie semiotycznej, a także lingwistycznej, używane są zarówno typy (types), jak i egzemplarze znaków (tokens). Często nie zwraca się tu jednak uwagi na to, kiedy mowa o typach, a kiedy o egzemplarzach ${ }^{6}$. Ma to związek z niedookreśleniem lub mieszaniem tych pojęć.

\section{Spory w sprawie statusu ontologicznego znaków językowych i relacji między nimi}

Problemy dotyczące natury ontologicznej typów i egzemplarzy znaku językowego są wciąż przedmiotem dyskusji w filozofii języka ${ }^{7}$. Rozróżnienie typ-egzemplarz jest dystynkcją ontologiczną pomiędzy ogólnym rodzajem przedmiotów a przedmiotami poszczególnymi. Spory dotyczące statusu ontologicznego tych znaków odnoszą się do takich problemów, jak:

- Czym jest typ?

- Czym jest egzemplarz (okaz, token)?

- Jakie są wzajemne relacje pomiędzy typami a egzemplarzami (ang. type-token relations)?

Spory te mają związek z zagadnieniami egzystencjalnymi co do natury ontologicznej tych znaków; wiążą się z dwoma nurtami w ontologii języka, pozostającymi pod wpływem dwóch idei w sporze o uniwersalia: nominalizmem i realizmem.

Rozważmy np. fragment wiersza Gertrudy Stein Święta Emily: „Róża to róża to róża to róża” i zapytajmy: „Ile jest w nim słów?”. Odpowiedź jest niejednoznaczna. W jednym sensie są dwa, a w innym jest ich siedem.

${ }^{4}$ Charles S. Peirce, "Letters to Lady Welby", w: The Essential Pierce, Selected Philosophical Writings, vol. 2 (1893-1913), wyd. Peirce Edition Project, ed. Nathan Houser i in. (Bloomington, IN: Indiana University Press, 1998), (1908) SS 83, 125, 480, 488.

5 Charles S. Peirce, "Letters to Lady Welby", w: The Essential Pierce, Selected Philo-sophical Writings, vol. 2 (1893-1913), Peirce Edition Project, ed. Nathan Houser i in. (Bloomington, IN: Indiana University Press, 1998), (1908) [c]MS [R]L463,15.

${ }^{6} \mathrm{~W}$ dalszym ciągu będziemy często stosować zamiennie słowa „egzemplarz" i „,token".

7 Problematyka ta jest szczegółowo omówiona przez Lindę Wetzel w: Stanford Encyklopedia of Philosophy, ed. Edward Zalta i in.: https://plato.stanford.edu/entries/ types-tokens/ (Stanford, CA: Stanford University, 2016). 
Odpowiedź zależy oczywiście od tego, czy chodzi nam o słowa-typy czy o słowa-egzemplarze (tokens).

Różnica znaczeniowa wiąże się też z pytaniem, czy typy są uniwersaliami. Odpowiedź zależy od tego, czym są uniwersalia (powszechniki). Znane nam są kontrowersje związane z tą kwestią. Odpowiedzi na to pytanie bywają takie:

1) Tak. Są one przecież abstraktami, nie mają lokalizacji przestrzenno-czasowej, choć mają instancje; istnieja, jeśli istnieja uniwersalia.

2) Nie. Nie są one uniwersaliami ani niezwykłymi obiektami; są one w swoich instancjach (podobnie jak uniwersalia; nie są abstraktami) ${ }^{8}$.

Wracając ponownie do pytania, czym są typy, i zakładając, że słowa-typy są paradygmatami typów w ogóle, można sformułować krótko kilka różnych, zupełnie odmiennych odpowiedzi przyjmowanych przez filozofów. Typy są:

- uniwersaliami, abstraktami, nie są widzialne, spostrzegalne, są bez lokalizacji';

- zbiorami dystrybutywnymi tokenów ${ }^{10}$, konstrukcjami;

- rodzajami, gatunkami (ale nie zbiorami) ${ }^{11}$,

- prawami ${ }^{12}$, które nie istnieja, ale są - zdecydowanie znaczącymi formami, które określają rzeczy, które istnieją;

- normami ${ }^{13}$ : bo typ obejmuje tokeny i ma wszystkie projektowalne cechy tokenów (tę samą fonologiczną strukturę słów i ten sam układ ich liter).

Nie ma też jednoznaczności $w$ odpowiedzi na pytanie, czym są egzemplarze znaków. Najczęściej zakłada się, że słowa-tokeny, egzemplarze, okazy są materialnymi, fizycznymi, zlokalizowanymi w czasie i przestrzeni obiektami - konkretami. Mogą one być utworzone z cząstek atramentu, tuszu długopisowego, pikseli światła, elektronicznych kropek czy kresek (lub ich braku) na ekranach komputera. Mogą też być

${ }^{8}$ Należy jednak zauważyć, że większość metafizyków uważa je za rodzaj uniwersaliów.

9 Stanowisko takie przyjmują w szczególności Edward N. Zalta i Michael Jubien. Zob. Edward N. Zalta, Abstract Objects: An Introduction to Axiomatic Metaphysics (Dordrecht: D. Reidel, 1983); Micheal Jubien, „On Properties and Property Theory”, w: Properties, Types and Meaning, vol. I: Foundational Issue, ed. Chierchia Genardo (Dordrecht, Holland: Kluwer Academic Publishers, 1988).

10 Zob. Willard van Quine, Quiddities: An Intermittently Philosophical Dictionary (Cambridge, MA: Harvard University Press, 1987), 218.

11 Zob. np. Nicholas Wolterstorff, Works and Works of Art (Oxford: Clarendon Press, 1980).

12 Charles S. Peirce, Collected Papers ofCharles Sander Peirce, ed. C. Hartshorne and P. Weiss. (Cambridge, MA: Harvard University Press, 1931-1935), sec. 4.537.

${ }_{13}$ Zob. Sylvian Bromberger, "Types and Tokens in Linguistic", w: Sylvian Bromberger, On What We Know We Don't Know (Chicago: University of Chicago Press, 1992), 170-208. 
sygnałami dymnymi czy świetlnymi, gestami rąk, falami dźwiękowymi itp.

Zasadnicza różnica pomiędzy typami słów i ich egzemplarzami zaznacza się $\mathrm{w}$ tym, że ten sam typ może posiadać różne egzemplarze. $\mathrm{Na}$ przykład typ o nazwie "znak” może posiadać następujące, różne, poniższe słowa egzemplarze:

$\begin{array}{ccccc} & \mathrm{Z} & & \\ & n & & & \\ \text { ZNAK } & & a & & \text { znak }\end{array}$

znak

Jest dość oczywiste, że nie może być zgodności w odpowiedzi na pytanie, jakie są relacje między typem a tokenami językowymi. Odpowiedź zależy bowiem od tego, jak pojmowany jest typ. I tak:

1) Jeśli typ jest zbiorem, to relacją typ-egzemplarz (ang. type-token relation) jest relacja przynależności do zbioru (przynależności egzemplarzy znaków języka do ich typu);

2) Jeśli typ jest klasa, to relacją tą jest relacja przynależności do klasy;

3) Jeśli typ jest rodzajem, to relacją tą jest relacja przynależności do rodzaju;

4) Jeśli typ jest prawem, to relacją tą jest, być może, relacja bycia użytym zgodnie z nakazem prawa.

Niemniej często uważa się, że relacją tą jest:

5) relacja tworzenia przykładu (instancji) czy egzemplifikacja (egzemplarze są przykładami lub egzemplifikacjami typu) - poglad instantacyjny (ang. instantiation view), lub

6) relacja reprezentowania typu przez egzemplarze - poglad reprezentacyjny (ang. representation view) ${ }^{14}$.

Te dwa ostatnie stanowiska poddane są zarzutom przez opozycyjne strony. I tak:

Zarzut wobec 5): Sa typy, które nie posiadaja egzemplarzy (np. nieskończenie długie

złożenia słów-typów).

Zarzut wobec 6): Sa instancje, które nie sa egzemplarzami typu i go nie reprezentuja.

Do obu tych poglądów i zarzutów wobec nich wrócimy jeszcze w dalszej części pracy.

${ }^{14} \mathrm{~W}$ przypadku 6) chodzi tak naprawdę o relację: egzemplarz-typ (ang. token-type relation). 
Uwaga: O relacjach typ-egzemplarz (ang. type-token) lub egzemplarz-typ (ang. token-type) sensownie jest mówić, gdy typy znaków w jakimś sensie istnieja, gdy w lingwistyce i filozofii języka mają pierwotną albo wtórną egzystencję.

Problem pierwotnego czy wtórnego bytowania znaków językowych $\mathrm{w}$ lingwistyce i filozofii wiąże się z odpowiedzią na pytanie: Czy lingwistyczny typ jest pierwotnym, czy też wtórnym ontologicznie wyrażeniem języka w stosunku do językowego tokenowego wyrażenia?

Problem ten wiąże się zatem niejako z odwiecznym zapytaniem: Czy pierwszy był duch czy materia? Gdy pragniemy opowiadać się za jakimś stanowiskiem $\mathrm{w}$ sprawie relacji type-token, powinniśmy określić, czy opowiadamy się:

- $w$ duchu Platońskim - za pierwotnym istnieniem typów (obiektów abstrakcyjnych), a wtórnym - tokenów (obiektów materialnych), czy też przeciwnie:

- $w$ duchu nominalistycznym, konkretystycznym - za pierwotnym istnieniem tokenów (realnie istniejących przedmiotów), a wtórnym typów.

\section{Rozwiqzywanie poruszanych problemów}

Akceptując Platońską wersję realizmu, stwierdza się, że: typ, jako byt wyizolowany, abstrakcyjny, jest niezależny od tokenów (one nie tworzą tego typu), choć możemy tokeny uważać za jego:

- fizyczne reprezentacje,

- egzemplifikacje, konkretyzacje czy instancje.

W tym wypadku możemy też stwierdzić, że relacją łączącą typy i tokeny jest bądź reprezentacja, bądź konkretyzacja, egzemplifikacja lub instantacja w tym sensie, że typy mogą wyznaczać ich reprezentacje, egzemplifikacje - tokeny, egzemplarze, które wtedy sa, odpowiednio, reprezentowane, egzemplifikowane czy też - są przykładami tych typów. Zależy to oczywiście od tego, jak ten typ pojmujemy.

Akceptując stanowisko konkretystyczne, stwierdza się, że: określone tokeny (językowe konkrety) wyznaczają i określają dany typ, który jest utworzony za ich pomoca, jest typem tokenów, egzemplarzy. Wtedy typ nie jest bytem niezależnym, lecz wtórnie istniejącym obiektem, wyabstrahowanym, wyodrębnionym z tokenów, a same tokeny mogą:

- tworzyć ten typ, konstruować ten typ,

- reprezentować ten typ.

Zależy to od tego, jak pojmujemy typologię czy logiczną abstrakcję.

W typologii typ jest tworem czy konstruktem abstrakcyjnym, obiektem abstrakcyjnym, wytworzonym, wyróżnionym, wyłonionym czy wyabstrahowanym myślowo, wygenerowanym z pewnych obiektów, które maja 
przynajmniej jedna wspólna własność. Typ jest wtedy zawsze typem jakichś obiektów, które mają co najmniej jedną tę samą wspólną własność. Zauważmy jednak, że typ jest niekoniecznie typem konkretnych obiektów, a więc niekoniecznie typem tokenów. Typ - jako obiekt abstrakcyjny - może być typem innych obiektów abstrakcyjnych, np. rzeczownik (jako część mowy) jest typem pewnych słów abstrakcyjnych, które to, jako wyłonione spośród tokenowych słów (napisów lub wypowiedzi) mających określone te same własności, same są typami - typami konkretów, znakowych tokenów.

$\mathrm{W}$ lingwistyce rozważa się $\mathrm{w}$ zasadzie językowe typy konkretów (dźwięków mowy, inskrypcji): typami sa proste słowa i zdania - abstrakcyjne wyrażenia językowe. Wyrażenia te mają swoje własne typy na poziomie meta-językowym. Te z kolei mają swoje własne typy na poziomie meta-metajęzykowym. Zauważmy jednak, że niezależnie od tego, jakie typy wyrażeń danego języka sa podstawa konkretnych badań lingwistycznych, wszystkie twierdzenia jezzyka lingwistyki (i ich składniki-słowa) sa wyrażeniami-typami ich tokenowych wyrażeń, konkretów.

\subsection{Pogląd instantacyjny a pogląd reprezentacyiny}

Rozważmy wzajemne zarzuty wobec opozycyjnych stanowisk w kwestii poglądów na funkcjonowanie relacji typ-egzemplarz.

1) Zarzuty zwolenników pogladu reprezentacyjnego przeciwko zwolennikom pogladu tworzenia instancji danego typu opierają się na sądzie, że filozofowie i lingwiści preferujący ten pogląd zakładają iż jedyną cechą przysługującą każdemu z egzemplarzy (tokenów) danego typu jest to, że mają one kształt czy brzmienie i że ten sam kształt albo to samo brzmienie wyróżnia je i pozwala tworzyć ich typ, wyłoniony przez tę wspólną ich własność, dokładnie tego samego fizycznego podobieństwa.

Myślę, że nieporozumienie bierze się stąd, że interpretatorzy, a może nawet i sami zwolennicy poglądu tworzenia instancji, nie odróżniają nazwy typu od tego typu, np. nazwy typu „kolor" od abstrakcyjnego bytu określonego tą nazwą. Ten abstrakcyjny byt, w tym wypadku, został bowiem wyróżniony, wygenerowany, wyabstrahowany dzięki konkretnym przedmiotom ze względu na to, że każdy z nich ma tę samą cechę: bycia przedmiotem kolorowym, którym w szczególności może być każda kolorowa inskrypcja (pisana w różnych kolorach) czy kolorowe serduszka lub gwiazdki, np.

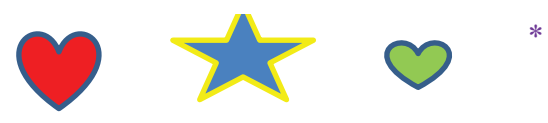


i każda kolorowa rzecz, np. konkretna kolorowa piłka dziecka. Ten abstrakcyjny byt powstaje - bądź jest traktowany - jako wspólna własność, która wyróżnia łącznie wszystkie te kolorowe przedmioty, ale nie jest własnością tych przedmiotów. Wspólna własność jest tworem abstrakcyjnym i nie może być traktowana jako własność każdego tokenu z osobna, nie może być ich dzieloną własnością. Argumentacja przeciwko pogladowi instantacyjnemu nie jest jednak zupełnie jasna i pełna.

Sądzę, że zwolennikom pogladu instantacyjnego może nie chodzi o to, że dany typ jest generowany przez tokeny, wyabstrahowany przez tokeny, ale że one są bytami wtórnymi, fizycznymi konkretyzacjami istniejących typów. Tylko w tym sensie tokeny sa instancjami ich typów (typy sa egzemplikowane przez tokeny). Wtedy ich stanowisko jest stanowiskiem platonizujacym. Przy innym założeniu - konkretystycznym, można też mówić, że tokeny reprezentują określony typ (typy sa reprezentowane przez tokeny).

Z formalnego, logicznego punktu widzenia typ oznaczony nazwą „kolor” jest konstrukcją logiczną konstrukcją teoriomnogościowa, abstrakcyjną klasą abstrakcji wszystkich tych przedmiotów, które są kolorowe. Nie można więc konkretnych kolorowych napisów o różnej lokalizacji czasowo-przestrzennej, ale mających jakiś kolor, traktować jako instancji typu określonego nazwą "kolor" poprzez fizyczne podobieństwo do inskrypcji znajdującej się wewnątrz cudzysłowu.

2) Zarzuty zwolenników poglądu instantacyjnego przeciwko zwolennikom pogladu reprezentacyjnego opieraja się - jak sadze - na stwierdzeniu, że nazwy-typu nie można identyfikować z przedmiotem oznaczanym ta nazwa. Nie można np. typu o nazwie „horse”, reprezentowanego przez np.

\section{horse HORSE}

uważać za "reprezentującego" poszczególne konie, jak sugeruje Zoltán Szabó$^{15}$ - przedstawiciel Representation View, a to przez porównanie ze znakami ikonicznymi, mapami, fotografiami, bo ikona reprezentuje to, co przedstawia. Nazwa "horse" oznacza poszczególne, konkretne konie, ale ich nie reprezentuje.

15 Zoltán Szabó, „Expressions and Their Representations”, The Philosophical Quarterly 49 (1999): 145-163. 


\section{Teoretyczne podejście do problemu wzajemnych relacji pomiędzy egzemplarzami i typami znaków}

\subsection{Składnia}

Formalizując składnię języka, zarówno na poziomie konkretów, jak i na poziomie typów, związki pomiędzy samymi znakami-egzemplarzami i samymi znakami-typami ${ }^{16}$, czyli odpowiednio:

$$
\mathrm{E} \rightarrow \mathrm{E} \text { oraz } \mathrm{T} \rightarrow \mathrm{T},
$$

a) mogą być wyznaczone przez reguły gramatyczne danego języka; są one wtedy relacjami formowania znaków złożonych z prostszych lub też

b) mogą być one określone przez nieodróżnialność znaków z pragmatycznego punktu widzenia; są nimi wtedy relacje: identyfikowalności (szeroko pojmowanej równokształtności) egzemplarzy $\simeq \mathrm{i}$, odpowiednio, tożsamości typów = , czyli:

$$
\mathrm{e} \simeq \mathrm{e}^{\prime} \operatorname{oraz} \mathrm{t}=\mathrm{t}^{\prime}, \text { dla e, } \mathrm{e}^{\prime} \in \mathrm{E}, \mathrm{t}, \mathrm{t}^{\prime} \in \mathrm{T},
$$

przy czym identyfikowalne e gzemplarze e i e' nie są zazwyczaj takie same, czyli:

$$
\text { (1) } \mathrm{e} \simeq \mathrm{e}^{\prime} \rightarrow\left(\mathrm{e} \neq \mathrm{e}^{\prime} \text { lub e }=\mathrm{e}^{\prime}\right),
$$

natomiast tożsame typy $\mathrm{t}$ i $\mathrm{t}^{\prime}$ są określone (są reprezentowane) przez te same egzemplarze, czyli jeśli typy te są klasami abstrakcji identyfikowalnych egzemplarzy, to

$$
\text { (2) } \mathrm{t}=\mathrm{t}^{\prime} \rightarrow \forall \mathrm{e} \in \mathrm{E}\left(\mathrm{e} \in \mathrm{t} \leftrightarrow \mathrm{e} \in \mathrm{t}^{\prime}\right) .
$$

Związki pomiędzy egzemplarzami i typami, czyli:

$$
\mathrm{E} \rightarrow \mathrm{T} \text { oraz } \mathrm{T} \rightarrow \mathrm{E}
$$

określają sposoby:

c) tworzenia typu z egzemplarzy zbioru E oraz, odpowiednio,

d) wskazywania egzemplarzy ze zbioru E przez typ.

16 Przez E oznaczamy zbiór znaków-egzemplarzy, krótko - tokenów, a przez T zbiór znaków-typów, krótko - typów. 
Dla sposobu c) chodzi o relację konstruowalności typu z egzemplarzy (wersja konkretystyczna: egzemplarze są elementami typów jako zbiorów czy klas; są one reprezentantami typów; zbiory-typy mogą być wtedy klasami abstrakcji identyfikowalnych egzemplarzy).

Dla sposobu d) relacją jest egzemplifikacja, konkretyzacja typu (wersja platonizujaca: typy są egzemplifikowane przez egzemplarze, są przez nie reprezentowane).

Uwaga: Można wykazać, że w rozważaniach syntaktycznych nad językiem opowiadanie się za jednym ze stanowisk: konkretystycznym czy platonizujacym może być pominięte ${ }^{17}$. Oba stanowiska są równoważne, co przemawia jednak na rzecz stanowiska konkretystycznego.

\subsection{Semantyka}

Podstawą badań syntaktycznych mogą być lingwistyczne słowa i wyrażenia-typy jako byty abstrakcyjne, twory utworzone z egzemplarzy, których jedyną cechą wspólną jest strukturalne podobieństwo (ortograficzne lub fonograficzne), a więc niekoniecznie fizyczne podobieństwo, ten sam kształt lub to samo brzmienie. Takie językowe wyrażenia-typy są zazwyczaj pozbawione znaczenia bądź mają wiele znaczeń. Jeśli chcemy im nadać jakąś własność semantyczno-pragmatyczną i przypisać im znaczenie czy znaczenia, w których są one używane w języku, a których wyjaśnianiem zajmują się konkretne słowniki języka, to należy je traktować jako wygenerowane nie tylko ze względu na zewnętrzną cechę strukturalną, formę ich linguistic externala (tokenów), lecz także ze względu na to, jak te tokeny są używane przez użytkowników języka w określonym kontekście sytuacyjno-językowym, w odniesieniu do realnej rzeczywistości lub rzeczywistości badanej, np. językowej.

Punktem wyjścia jest wtedy relacja use używania egzemplarzy języka przez użytkowników języka w odniesieniu do pozajęzykowych obiektów zwanych ich referentami czy korelatami lub też odniesieniami przedmiotowymi.

Podstawowe pojęcia semantyczne: znaczenie, oznaczanie, denotacja znaku językowego są określane na poziomie typów, a więc dla znaków-typów. W podejściu semantyczno-pragmatycznym ich definicje wymagają jednak odwołania się do pojęć semantyczno-pragmatycznych poziomu konkretów, w szczególności do pojęcia relacji use używania egzemplarzy, oraz do pojęcia relacji use używania ich typów, definiowanego za pomocą relacji use w następujący sposób:

17 Twierdzenie to jest uzasadniane w artykułach: Urszula Wybraniec-Skardowska, „Logiczne podstawy ontologii składni języka”, Studia Filozoficzne 6-7 (1988): 263-284; tenże, „On the Eliminability of Ideal Linguistic Entities” XLVIII, 4 (1989): 587-615. 
(Def. Use) Użytkownik $u$ używa typu tw sensie use wtedy i tylko, gdy używa on w sensie use jakiegoś egzemplarza typu $t$.

Same językowe tokeny (egzemplarze, konkrety) nie mają znaczenia ani desygnatów czy też denotacji (mogą być jedynie używane w sensie use w znaczeniu określanym przez ich typy). Dwa różne egzemplarze $e$ i $e^{\prime}$ moga mieć jednak to samo odniesienie przedmiotowe p. Relacjac łączącą egzemplarze $e i e^{\prime}$ jest wtedy relacja tego samego sposobu użycia egzemplarzy przez użytkownika jezyka (patrz Rys. 1).

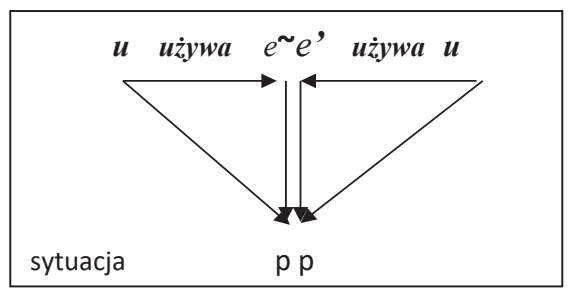

Rys. 1.

Znaczenie typu znaku językowego $t$ definiuje się jako wspólną własność znaków typów mających ten sam sposób użycia jak $t$, przy czym relacją łączącą typy $t i t^{\prime}$ jest wtedy relacja $\approx$ tego samego sposobu użycia typów $t$ i $t^{\prime}$ o definicji18: (Def. $\approx$ ) $t \approx t$ ' wtedy i tylko, gdy dowolny użytkownik języka $u \dot{z} y w a$ typu $t w$ sensie use wtedy $i$ tylko, gdy używa też typu $t^{\prime}$ w sensie use oraz używa on $w$ sensie use jakiegoś egzemplarza e typu $t w$ odniesieniu do przedmiotu $p$ wtw, gdy używa on też w sensie use jakiegoś egzemplarza e' typu $t^{\prime} w$ odniesieniu do tego samego przedmiotu $p$.

\subsection{Znaki w komunikacji językowej}

$\mathrm{W}$ akcie komunikacji pomiędzy nadawcą $n$ a odbiorcą $o$ znaku uczestniczą znaki-egzemplarze. Poniższe Rysunki 2a i $2 b$ ilustrują sytuację, gdy mamy do czynienia $\mathrm{z}$ aktami komunikacji za pomocą jednego albo dwóch różnych znaków-egzemplarzy e $i e^{\prime}$, gdzie $p$ oznacza przedmiot odniesienia egzemplarza $e$, natomiast $p^{\prime}$ przedmiot interpretacji znaku $e \operatorname{czy} e^{\prime}$.

18 Por. Urszula Wybraniec-Skardowska, „Meaning and Interpretation”, part I, Studia Logica 85, 1 (2007): 120-121. 

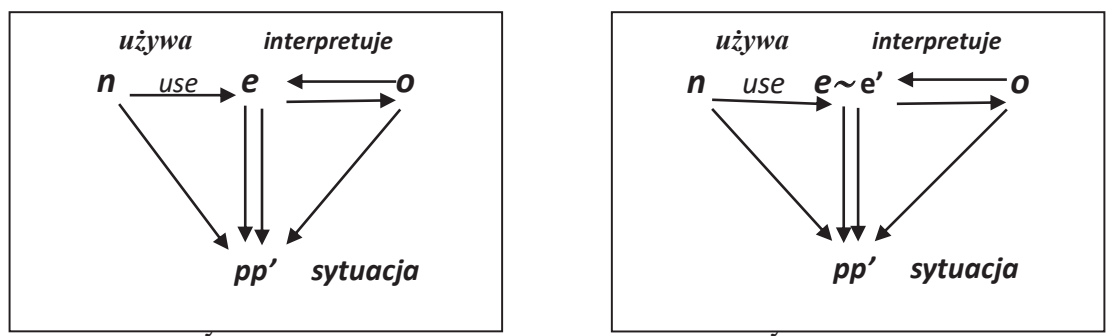

Rys. 2a Rys. 2b

Ogólne pojęcie komunikacji językowej pomiędzy potencjalnym nadawca $\mathrm{N}$ i potencjalnym odbiorca $\mathrm{O}$ wymaga pośredniczenia w niej jakiegoś typu znakowego $t$.

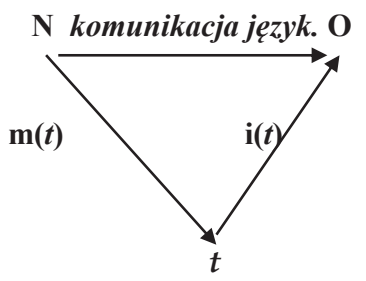

Rys. 3

Pojęcie to ilustruje Rysunek 3 - $\mathrm{m}(t)$ oznacza w nim znaczenie znaku-typu $t$, natomiast $\mathrm{i}(t)$ jego interpretację.

\section{Podsumowanie}

Z teoretycznego i logicznego punktu widzenia:

- Wypracowanie jakiejś teoretycznej koncepcji języka musi uwzględniać jego dwuaspektową charakterystykę: jako języka wyrażeń-konkretów i jako języka wyrażeń-typów,

- opowiedzenie się za jednym ze stanowisk:

a) typy istnieją niezależnie od ich egzemplarzy (stanowisko platonizujace) albo

b) tak nie jest (stanowisko konkretystyczne) może być pominięte $\mathrm{w}$ rozważaniach syntaktycznych nad językiem.

- Wzajemne związki pomiędzy znakami-egzemplarzami różnią się od wzajemnych związków pomiędzy znakami-typami, ale

- określenie wzajemnego stosunku pomiędzy znakami-typami a znakami-egzemplarzami zależy od opowiedzenia się za jednym ze stanowisk: a) albo b); 
- pojęcia semantyczne, czy semantyczno-pragmatyczne języka, takie jak: znaczenie i denotacja, interpretacja, powinny być definiowane wyłącznie dla typów egzemplarzy, ale ich definicje wymagają jakiegoś odniesienia do funkcji, jakie pełnią w języku znaki (słowa, wyrażenia) konkrety, czy do związków między nimi;

- pojęcie aktu komunikacji językowej różni się od ogólnego pojęcia komunikacji językowej: to pierwsze definiuje się za pomocą znaków-konkretów, podczas gdy to drugie - za pomocą znaków-typów.

\section{Podziękowanie}

Składam serdeczne podziękowanie Recenzentom artykułu za wnikliwe uwagi i życzliwe sugestie, które pozwoliły mi na ulepszenie jego pierwotnej wersji.

\section{Bibliografia}

Bromberger Sylvian. 1992. „Types and Tokens in Linguistic”. W: Sylvian Bromberger. On What We Know We Don't Know. 170-208. Chicago: University of Chicago Press.

Jubien Michael. 1988. "On Properties and Property Theory". W: Properties, Types and Meaning. Vol. I: Foundational Issue, ed. Chierchia Genardo. Dordrecht, Holland: Kluwer Academic Publishers.

Peirce Charles S. 1906. „Prolegomena to an Apology for Pragmaticism”. Monist 16: 492-546.

Peirce Charles S. 1931-1935. Collected Papers of Charles Sanders Peirce. Vols. 1-5, ed. C. Hartshorne and Weiss P. Cambridge, MA: Harvard University Press.

Peirce Charles S. 1998. „Letters to Lady Welby”. W: The Essential Pierce, Selected Philosophical Writings. Vol. 2 (1893-1913), wyd. Peirce Edition Project, ed. Nathan Houser i in., 1908[c]. SS 83. Bloomington, IN: Indiana University Press.

Peirce Charles S. 1998. „Letters to Lady Welby”. W: The Essential Peirce, Selected Philosophical Writings. Vol. 2 (1893-1913), wyd. Peirce Edition Project, ed. Nathan Houser i in., 15. 1998, MS [R] L463:15. Bloomington, IN: Indiana University Press.

Peirce Charles S. 1998. The Essential Pierce, Selected Philosophical Writings. Vol. 2 (1893-1913), wyd. Peirce Edition Project, ed. Nathan Houser i in., Bloomington, IN: Indiana University Press.

Pelc Jerzy. 1971. „Funkcjonalne podejście do semiotyki logicznej języka naturalnego". W: Semiotyka polska 1894-1969, wyboru dokonał oraz wstępem i przypisami opatrzył Jerzy Pelc. 397-430. Warszawa: PWN. 
Pelc Jerzy. 1971. Studies in Functional Logical Semiotics of Natural Language. Janua Linguarum Series Minor 90. The Hague-Paris: Mouton.

Quine Willard Van. 1987. Quiddities: An Intermittently Philosophical Dictionary. 216-219. Cambridge, MA: Harvard University Press.

Szabó Zoltán. 1999. „Expressions and Their Representations”. The Philosophical Quarterly 49: 145-163.

Wetzel Linda. 2016. „Types and Tokens”. W: Stanford Encyclopedia of Philosophy, ed. Edward N. Zalta i in.: https://plato.stanford.edu/entries/type-tokens/. Stanford, CA: Stanford University.

Wolterstorff Nicholas. 1980. Works and Works of Art. Oxford: Clarendon Press. Wybraniec-Skardowska Urszula. 1988. „Logiczne podstawy ontologii składni języka". Studia Filozoficzne 6-7: 263-284.

Wybraniec-Skardowska Urszula. 1989. „On the Eliminability of Ideal Linguistic Entities". Studia Logica XLVIII, 4: 587-615.

Wybraniec-Skardowska Urszula. 2010. „O adekwatności językowej”. W: Deskrypcja i Prawda, red. Jerzy Pelc. 275-306. Warszawa: Polskie Towarzystwo Semiotyczne.

Wybraniec-Skardowska Urszula. 2015. „On language adequacy”. Studies in Logic, Grammar and Rhetoric 40, 53: 247-292.

Wybraniec-Skardowska Urszula. 2007. „Meaning and Interpretation”, part I, Studia Logica 85, 1: 105-132.

Zalta Edward N. 1983. Abstract Objects: An Introduction to Axiomatic Metaphysics. Dordrecht: D. Reidel.

\section{Streszczenie}

Tematyka pracy obejmuje wymienione poniżej zagadnienia czy problemy:

- Zagadnienie statusu ontologicznego znaków językowych i wiążący się z nim ogólniejszy problem filozoficzny:

- Czym jest język jako system znaków, który z jednej strony służy do:

1) reprezentowania naszej wiedzy o poznawanej rzeczywistości, a z drugiejdo

2) a. jej zgłębiania i lepszego poznawania czy odkrywania,

b. adekwatnego jej opisu, oraz

c. interpersonalnego komunikowania się jego użytkowników.

Wszystkie te pragmatyczne funkcje języka wymagają logiczno-filozoficznej jego analizy i to zarówno jego składni, jak i semantyki. Nie jest ona możliwa bez określenia, jak pojmowane są znaki językowe, jaka jest ich ontologiczna natura w funkcjonalnym podejściu do logicznej semiotyki języka naturalnego, osadzonym na dwóch sposobach ich użycia: bądź jako znaków, którymi posługujemy się w konkretnych kontekstach sytuacyjnych czy sytuacyjno-językowych, bądź jako znaków izolowanych, oderwanych z takich kontekstów.

W tym pierwszym wypadku są one konkretami językowymi, istniejącymi materialnymi, spostrzegalnymi zmysłowo obiektami o określonej lokalizacji czasoprzestrzennej, w tym drugim - są one nie-konkretami, a jako takie (jak przyjmuje 
większość badaczy z zakresu filozofii i lingwistyki) - obiektami abstrakcyjnymi, typami językowymi.

Rozróżnienie abstrakt-konkret (ang. type-token distinction) ma już we współczesnej filozofii pewien status i jest znaczące zwłaszcza w metafizyce i epistemologii. Jest ono najczęściej ilustrowane właśnie w odniesieniu do znaków językowych (słów, wyrażeń) jako dystynkcja typ-egzemplarz znaku, wprowadzona do semiotyki przez Ch. S. Peirce'a.

W analizie semiotycznej, a także lingwistycznej, używane są zarówno typy, jak i egzemplarze znaków, często jednak bez zwracania należytej uwagi, kiedy mowa o typach, a kiedy o egzemplarzach. Ma to związek z dyskutowanymi wciąż w filozofii języka problemami: Czym jest typ? Czym jest egzemplarz (okaz)? Jakie są wzajemne relacje pomiędzy typem a egzemplarzem? (ang. type-token relation, token-type relation).

Spory w odpowiedzi na te pytania mają związek z zagadnieniami egzystencjalnymi dotyczącymi statusu ontologicznego tych znaków językowych oraz dwoma nurtami w ontologii języka, pozostającymi pod wpływem dwóch fundamentalnych idei, które ukształtowały się w sporze o uniwersalia: nominalizmem i realizmem.

Autorka przedstawia, krótko, różne stanowiska w sprawie poruszanych powyżej zagadnień czy problemów oraz utrzymuje, że z logicznego punktu widzenia:

1) wypracowanie jakieś teoretycznej koncepcji języka musi uwzględniać jego dwuaspektową charakterystykę: jako języka wyrażeń-konkretów i jako języka wyrażeń-typów,

2) opowiedzenie się za jednym ze stanowisk:

a) typy istnieją niezależnie od ich egzemplarzy albo

b) tak nie jest może być pominięte w rozważaniach syntaktycznych nad językiem,

3) wzajemne związki pomiędzy znakami-egzemplarzami różnią się od wzajemnych związków pomiędzy znakami-typami, ale

4) określenie wzajemnego stosunku pomiędzy znakami-typami a znakami-egzemplarzami zależy od opowiedzenia się za jednym ze stanowisk: a) albo b),

5) pojęcia semantyczne, czy semantyczno-pragmatyczne języka, takie jak: znaczenie i denotacja, interpretacja, powinny być definiowane wyłącznie dla typów egzemplarzy, ale ich definicje wymagają jakiegoś odniesienia do funkcji, jakie pełnią w języku znaki (słowa, wyrażenia) konkrety, czy do związków między nimi;

6) pojęcie aktu komunikacji językowej różni się od ogólnego pojęcia komunikacji językowej: to pierwsze definiuje się za pomocą znaków-konkretów, podczas gdy to drugie - za pomocą znaków-typów.

Słowa kluczowe: znaki-egzemplarze, typy znaków, dualny status znaków językowych, nominalizm i realizm w filozofii języka, relacje między znakami 


\section{The Double Ontological Nature of Language Signs and the Problem of Their Mutual Relations}

\section{Summary}

The subject matter of this work covers the issues or problems listed below:

$\varnothing$ The problem of the ontological status of language signs and a more general philosophical problem connected with it:

$\varnothing$ What is language as a system of signs, which - on the one hand - serves to:

1) represent our knowledge about the reality which is being recognized, and, on the other one to:

2) a. explore and better cognize or discover it,

b. describe it in an adequate manner, and

c. enable users to make interpersonal communication?

All the pragmatic functions of language require carrying out its logical-philosophical analysis, and this means both regarding its syntax and semantics. Such an analysis is not possible without determining the following: How are signs perceived and what is their ontological nature in the so-called functional approach towards logical semiotics of natural language, founded on two ways of their usage: either as signs which we use in concrete situational or situational-language contexts or as isolated signs detached from such contexts?

In the first case, they are language tokens (concretes), existing material objects perceived through the senses, with a fixed temporal-spatial location, in the other one - they are non-concretes and as such (as the majority of researchers in the field of philosophy and linguistics accept) - abstract objects, language types.

The type-token distinction (differentiation between abstract and concrete) has already acquired a certain status in contemporary philosophy and is of considerable importance to metaphysics and epistemology in particular. Indeed, it is most often illustrated with reference to language signs (words, expressions) as the distinction type/token of a sign, introduced into semiotics by Ch. S. Peirce.

In the semiotic analysis, and also in the linguistic one, there are used both types and tokens of signs, however, often without paying due attention to when it is said about types and when about tokens. This is related to the problems which are still considered by the philosophy of language: What is the type? What is the token (specimen)? What are the mutual relations between the type and the token?

Disputes concerning providing answers to these questions are related to existential issues dealing with the ontological status of these language signs and two currents within the ontology of language, remaining under the influence of two fundamental concepts formed in the debate: nominalism and realism.

The author presents in brief different stances on the above-mentioned issues or problems, as well as argues that from the logical point of view:

1) working out any theoretical conception of language must take into account its bi-aspectual characteristics: as a language of expression-tokens and as a language of expression-types; 
2) advocating either of the standpoints: (a) types exist independent of their tokens, or (b) it is not so, can be omitted in syntactic considerations on language;

3) mutual relations between sign-tokens differ from the mutual relations between sign-types, yet;

4) determination of the mutual relation between sign-types and sign-tokens depends on accepting either of the standpoints: (a) or (b);

5) semantic or semantic-pragmatic concepts of language, such as meaning, denotation, interpretation should be defined exclusively for types of tokens, but their definitions require certain reference to the functions which signtokens perform in the language (words, expressions), or to relations between them;

6) The concept of an act of language communication differs from general language communication: the first one is defined by means of sign-tokens, whereas the other one - with the use of sign-types.

Keywords: sign-tokens, sign-types, dual ontological status of language signs, nominalism and realism in philosophy of language, token-token relations, typetype relations, type-token relations 